\title{
UTJECAJ PERSPEKTIVE I REJTINGA IGRAČA NA FLEKSIBILNO MIŠLJENJE U ŠAHU
}

\author{
Marko Antolčić \\ Odjel za psihologiju, Sveučilište u Zadru \\ Obala kralja Petra Krešimira IV 2, 23000 Zadar \\ marko.antolcic@gmail.com \\ Pavle Valerjev \\ Odjel za psihologiju, Sveučilište u Zadru \\ Obala kralja Petra Krešimira IV 2, 23000 Zadar \\ valerjev@unizd.hr
}

\begin{abstract}
Sažetak
Einstellung efekt (E-efekt) se u psihologiji šaha opisuje kao mentalni set koji šahiste čini nefleksibilnima da optimalno riješe problemsku poziciju, kad je u poziciji prisutno drugo poznato rješenje. Percepcija iskusnih šahista funkcionira tako da im omogućuje brzo uočavanje odnosa među figurama grupirajući ih u konfiguracije, što rezultira brzim pronalaskom poznatog rješenja. Pri tome glavnu ulogu ima tzv. brzi mehanizam poput prepoznavanja, dok bi za pronalazak optimalnog rješenja u istoj situaciji bio potreban izraženiji spori mehanizam, kao što je pretraživanje polja za mogućim potezima. Tehnika koja potiče aktivaciju sporog mehanizma mogla bi biti obrnuta perspektiva opažanja šahovske pozicije. U situaciji kad brzi mehanizam nije efikasan, ako se pozicija učini perceptivno nejasnijom, možda se potakne drugačiji pristup uspostavljanja odnosa među figurama. Cilj istraživanja bio je ispitati utjecaj obrnute perspektive na smanjenje E-efekta, te utvrditi utjecaj rejtinga na nastanak Eefekta. U eksperimentu su sudjelovali klupski igrači $(N=26)$ s nacionalnim šahovskim rejtingom kojima se zadavao niz šahovskih problema u kojima se manipuliralo perspektivom. Ispitan je utjecaj perspektive i rejtinga na učestalost optimalnog rješenja, vrijeme odlučivanja, vremena i broja fiksacija na poljima relevantnim za Einstellung rješenje te razine sigurnosti u rješenje. Rezultati upućuju na to da obrnuta perspektiva nije imala efekt na niz zavisnih varijabli, dok se pokazalo da je redoslijed zadavanja problema utjecao na vrijeme odlučivanja. Također, utvrđeno je da su šahisti višeg rejtinga imali češće optimalno rješenje i veću razinu sigurnosti. Rejting igrača pokazuje najjači efekt na fleksibilno mišljenje u šahu.
\end{abstract}

Ključne riječi: šah, obrnuta perspektiva, Einstellung efekt, fleksibilnost mišljenja 


\section{UVOD}

Adekvatna percepcija i pamćenje su ključne kognitivne komponente za postizanje visokih rezultata $u$ šahu. Perceptivni procesi omogućuju da igrač brzo prepozna srž kratko prezentirane pozicije (Charness, Reingold, Pomplun i Stampe, 2001). Također, de Groot i Gobet (1996) pokazuju da jaki šahisti mogu gotovo savršeno rekonstruirati kratko prikazanu šahovsku poziciju. Isti autori smatraju da su pamćenje i percepcija važniji u diferenciranju šahovske ekspertize nego sposobnost razmišljanja unaprijed u potrazi za optimalnim potezima, odnosno za najboljim potezima $u$ danoj poziciji, bilo da vodi do mata ili pozicijske prednosti. Istraživanja su pokazala (Chase i Simon, 1973; Frey i Adesman, 1976) da vrsni šahisti nemaju opću prednost u pamćenju nad slabijim šahistima, već da postoji razlika kada moraju upamtiti kratko prezentiranu poziciju. Takav nalaz implicira da se eksperti dobro snalaze u poznatijim okolnostima, ali ne toliko u situacijama gdje ne mogu primijeniti svoje stečeno znanje (Gobet i Simon, 1998).

Nadalje, Chase i Simon (1973) smatraju da se prednost vještih igrača nalazi u perceptivnoj organizaciji i mentalnoj reprezentaciji šahovske pozicije. Oni navode da šahisti s titulom majstora pretražuju podjednak broj mogućnosti kao i slabi igrači, no majstori su dobri u uvidu ispravnih poteza za daljnje razmatranje, dok slabi igrači troše znatnu količinu vremena analizirajući konsekvence slabih poteza (poteza kojima gube prednost). Iskusni šahisti automatski uspostavljaju odnose među figurama, time što automatskim i paralelnim procesima obrađuju relevantne informacije koje pridonose uspostavljanju pozicijske konfiguracije (Charness, i sur., 2001), a dinamična priroda percepcije im omogućava anticipaciju idućeg poteza (Ferrari, Didierjean i Marmèche, 2006). Ono što razlikuje iskusne šahiste od početnika su perceptivni procesi koji omogućuju kodiranje informacija u chunkove (Gong, Ericsson i Moxley, 2015), jedinice pamćenja koje sadrže ujedinjeni skup međusobno povezanih informacija i time manje zauzimaju kapacitet kratkoročnog pamćenja (Miller, 1956). Isprepletenost perceptivnih procesa i pamćenja uočava se u tome da ekspert u šahu koristi do 100000 (Simon i Gilmartin, 1973), a u kasnijem radu procijenjeno i do 300000 chunkova (Gobet i Simon, 2000). Korištenje chunkova, izraženo kroz brzo uočavanje ‘jakih' poteza (onih koji omogućuju prednost), prvo je stečeno sporim deduktivnim procesima (usvajanjem pravila) $\mathrm{i}$ iskustvom igranja različitih pozicija, a zatim brzim perceptivnim nesvjesnim procesiranjem (korištenjem percipiranih znakova) (Chase i Simon, 1973).

Istraživači (Chase i Simon, 1973; Frey i Adesman, 1976) sugeriraju da je potrebno dvije sekunde da se određeni chunck prepozna i da se njegova oznaka pohrani u kratkoročno pamćenje. Chunk služi kao identifikator u kratkoročnom pamćenju na temelju kojeg se onda locira i evaluira sadržaj iz dugoročnog pamćenja (Ferrari i sur., 2006). Efikasnost pamćenja odražava se u većem broja informacija kategoriziranih u skupove, što omogućava šahistu brže pretraživanje potencijalnih poteza $i$ 
njihovu klasifikaciju. Dakle, ono što određuje superiornost iskusnog igrača je brzo kodiranje informacija pozicija figura (Ferrari i sur., 2006) koje sadrže relacije međusobne obrane, njihovu udaljenost, napad na malim udaljenostima, kao i tip i boju figure. Takve informacije su kodirane u perceptivne chunkove kao poznata potkonfiguracija figura (Chase i Simon, 1973; Ferrari i sur., 2006). Navedeni autori također ističu hijerarhijsku organizaciju chunkova kod vještih igrača, koja je apstraktnija nego jednostavna organizacija chunk informacija. Ono što omogućava igraču da koristi chunkove jest to da se njegovo vidno pretraživanje pozicije odvija na rubovima polja, čime može zahvatiti veći broj figura u jednoj fiksaciji. Također, distanca među fiksacijama je veća, čime se isto tako prekriva veće područje pri fiksaciji. Navedeni nalazi ukazuju na tendenciju da vješti igrači prije percipiraju grupe figura nego individualne figure (de Groot i Gobet, 1996; Charness i sur., 2001). To govori o važnosti parafovealnog procesiranja šahovskih konfiguracija u vođenju pokreta očiju, što omogućuje šahistu da ima obuhvatniji i efikasniji pristup prepoznavanja obrazaca u poziciji (Charness i sur., 2001).

Korištenje složene perceptivne organizacije i izuzetnog pamćenja može imati i nepovoljan efekt prilikom rješavanja problema. Luchins (1942) je pokazao negativan utjecaj mentalnog seta u klasičnom eksperimentu s problemima s posudama za vodu. U tom istraživanju, ispitanici bi naučili rješavati problem pretakanja posuda s vodom na jedan način u uzastopnim serijama te im je onda zadan kritičan problem koji se mogao riješiti na već naučeni način, ali i brži, odnosno optimalan način. Ispitanici su imali tendenciju odabirati već naučeni način za razliku od onih ispitanika koji uopće nisu bili pripremani, te se takav efekt naziva Einstellung efekt (E-efekt). E-efekt se pojavljuje i u šahu kod igrača sa znatnim iskustvom. Istraživači (Saariluoma, 1990; Bilalić, McLeod i Gobet, 2008a) pokazuju kako višestruko izlaganje jednakom postupku rješavanja problema vodi istom pristupu rješavanja u daljnjim sličnim problemima. Iskusnim šahistima nije potrebno prethodno upoznavanje postupka rješavanja, jer su oni kroz iskustvo stekli veliki broj poznatih motiva (chunkova) odnosno rješenja u problemskim pozicijama. Stoga, iskusni šahisti već imaju dispoziciju za E-efekt kada je prisutan poznati motiv, tj. poznato rješenje, koje aktivira automatske perceptivne procese temeljene na iskustvu (Reingold, Charness, Schultetus i Stampe, 2001; Ellis i Reingold, 2014). U više radova (Bilalić i sur., 2008a; 2010; Sheridan i Reingold, 2013) navodi se da šahisti, u problemima s poznatim i optimalnim rješenjem, odabiru poznato rješenje te fiksacijom na njega ne uspijevaju pronaći optimalno rješenje. Nadalje, isti autori navode da šahisti, nakon pronalaska poznatog rješenja, izvještavaju da traže bolje rješenje, iako podaci praćenja očiju pokazuju da se i dalje usmjeravaju na značajke već pronađenog rješenja, osim ako se radi o previdu, gdje se relativno lakše distanciraju (Sheridan i Reingold, 2013). Autori više radova (Bilalić i sur., 2008a; Anderson i Lebiere, 1998; Logan, 1988) ističu kako je E-efekt toliko jak da su samo velemajstori otporni na njegov utjecaj, dok su ostali šahisti relativno podložni. Poznati potezi (Einstellung 
potezi) su praćeni kraćim vremenom odlučivanja, dok je za pronalazak optimalnog poteza potrebno duže vrijeme (Bilalić i sur., 2008b), jer poznati kontekst pruža veću sigurnost i brži pronalazak poteza, što snižava potencijalnu reevaluaciju pozicije. Drugim riječima, poznati kontekst se pokazao efikasnim za rješavanje problema u nizu situacija, što onda može doprinijeti usidrenoj perspektivi.

Da bi se smanjio utjecaj E-efekta, bilo bi potrebno nadjačati aktivaciju brzog mehanizma prepoznavanja korištenjem sporog mehanizma pretraživanja (Burns, 2004). Obrnuta perspektiva pri opažanju šahovske ploče mogla bi utjecati na procese percepcije prilikom odigravanja šahovskog poteza tako što bi smanjila perceptivnu jasnoću pozicije i potencijalno distancirala od automatskog prepoznavanja obrasca rješavanja (Amabile, 1989). Nadalje, obrnuta perspektiva može djelovati tako što šahist prilikom vlastitog napada ima perceptivni uvid u protivnikovu obra$\mathrm{nu}$, jer su mu protivničke figure bliže; dok u slučaju konvencionalne perspektive ima perceptivni uvid vlastitog napada, jer su vlastite figure bliže. Također, prilikom svoje obrane, u obrnutoj perspektivi, šahist ima perceptivni uvid u protivnički napad, ali slabiji perceptivni uvid u svoju obranu. Takav pristup poziciji mogao bi, zbog izmijenjenog načina uspostavljanja referentnih točaka, inhibirati automatsko prepoznavanje, i omogućiti fleksibilnije mišljenje u svrhu potrage za alternativnim kombinacijama.

\section{CILJEVI I HIPOTEZE}

Ciljevi istraživanja su ispitati utjecaj obrnute perspektive te utjecaj razine šahovskog rejtinga na smanjenje Einstellung efekta u šahovskim pozicijama i na druge parametre izvedbe.

Pretpostavlja se da će obrnuta perspektiva utjecati na veću frekventnost optimalnog rješenja, duže vrijeme odlučivanja, i nižu razinu sigurnosti u vlastiti odgovor. Također, očekuje se da će obrnuta perspektiva utjecati na veći udio vremena $i$ broja fiksacija na poljima za optimalno rješenje, a manje na poljima za Einstellung rješenje nego u konvencionalnoj perspektivi. Konačno, očekuje se da će ispitanici s višom razinom šahovskog rejtinga imati podjednaku zastupljenost utjecaja Einstellung efekta kao i šahisti nižeg rejtinga, osim što će imati višu razinu sigurnosti i kraće vrijeme odlučivanja.

\section{METODA}

\section{Ispitanici i nacrt}

Ispitanike su činili igrači šahovskog kluba Sisak i šahovskog kluba Zadar, te registrirani igrači sa Sveučilišta u Zadru (N = 26; 23 muška). Svi ispitanici 
imaju nacionalni rejting, koji označava jačinu igrača s obzirom na ostale šahiste na nacionalnoj razini, gdje je viši rejting ujedno veća jačina igrača. Uzorak je uključivao raspon od šahista druge kategorije do majstorskih kandidata (rejting ispitanika se kretao od 1591 do 2288 bodova nacionalnog rejtinga). Nacrt eksperimenta je bio faktorski 2 (perspektiva) $\times 2$ (redoslijed) eksperiment s ponovljenim mjerenjima.

\section{Materijali i mjerni instrumenti}

U istraživanju su korištena četiri šahovska problema opisana u radu Bilalića i suradnika (2008a) i dva demonstracijska problema. Problemi su sastavljeni i prezentirani pomoću programa Ogama 5.0, u dva tipa redoslijeda (1 i 2) i dvije perspektive (konvencionalna i obrnuta) (Slika 1). Nadalje, korišten je i sustav za praćenje očiju The Eye Tribe koji je bilježio očne fiksacije na odabranim šahovskim poljima. Uređaj je bilježio broj očnih fiksacija i provedeno vrijeme promatranja ključnih šahovska polja. Ključna šahovska polja za su bila softverski unaprijed označena. Softverski se bilježilo vrijeme rješavanja, frekvencije optimalnih poteza, procjena sigurnosti u vlastiti odgovor, vrijeme i broj očnih fiksacija na ključnim šahovskim poljima.

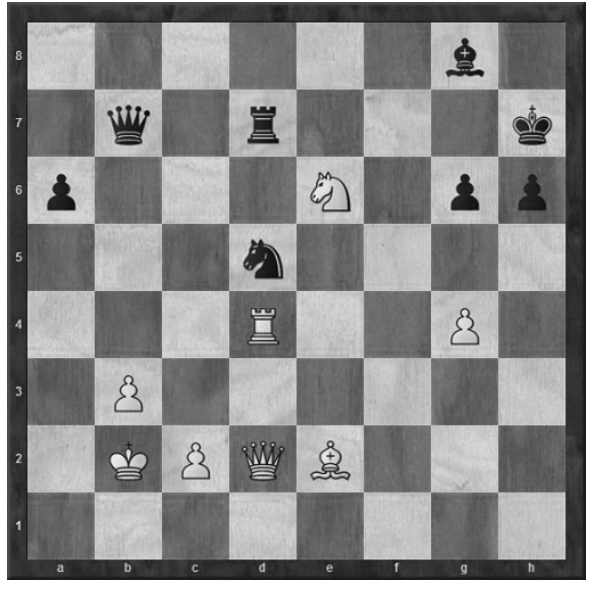

a) Konvencionalna perspektiva (KP1)

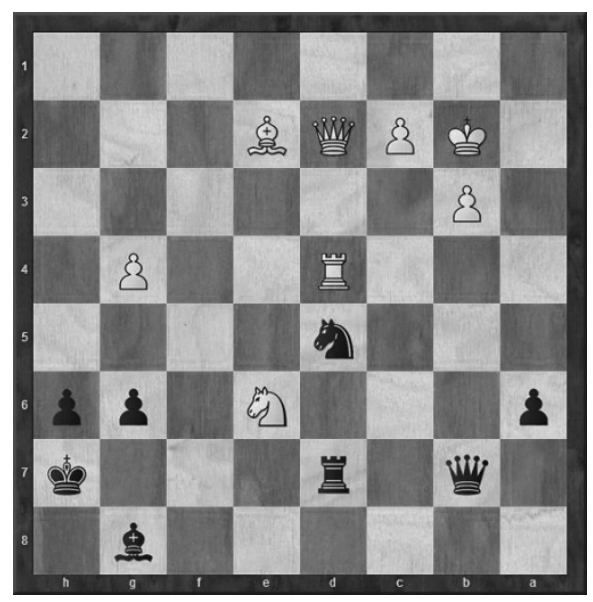

b) Obrnuta perspektiva (OP1)

Slika 1. Prikaz korištenog eksperimentalnog problema (problem 1) s obzirom na perspektivu 


\section{Postupak}

Ispitivanje je provedeno individualno $u$ Laboratoriju za eksperimentalnu psihologiju Odjela za psihologiju Sveučilišta u Zadru, a zadatak ispitanika bio je da pokuša riješiti zadane šahovske probleme. Za svakog ispitanika prvo je obavljen postupak kalibracije uređaja za praćenje očiju, pri čemu se uređaj prilagodio specifičnostima očnih pokreta i očnih fiksacija pojedinog ispitanika. Nakon toga su slijedila dva relativno jednostavna šahovska problema radi vježbe. Nadalje, slijedili su eksperimentalni problemi za koje je ispitanik, nakon svakog rješenja, izvještavao stupanj sigurnosti u svoj odgovor. Procjena sigurnosti je izražena kao postotak u rasponu $0-100 \%$ sigurnosti, gdje je $0 \%$ označavalo da ispitanik nimalo nije siguran u svoj odgovor, dok je $100 \%$ označavalo da je ispitanik potpuno siguran u svoj odgovor. Vremensko ograničenje rješavanja je bilo 5 minuta po problemu.

Problemi su bili rotirani unutar svakog bloka s posebnom perspektivom. U redoslijedu 1 prvo se rješavao blok od dva problema iz konvencionalne perspektive, a onda dva iz obrnute perspektive, a u redoslijedu 2 obrnutim redom. Ispitanici su po slučaju podijeljeni u dvije skupine te su, ovisno kojoj skupini su pripadali, rješavali probleme prema redoslijedu 1 ili 2.

\section{REZULTATI}

Deskriptivni podaci iz Tablice 1 pokazuju da su sudionici u prosjeku iskusni šahisti (na što upućuje raspon rejtinga), stoga se pretpostavlja da su upoznati s čestim primjerima motiva iz šahovskih partija i s korištenim motivima u ovom istraživanju. Proporcije vremena i broja fiksacija odnose se na udio vremena i na broj

Tablica 1. Deskriptivni parametri konvencionalne (KP) i obrnute (OP) perspektive

\begin{tabular}{lccccr}
\hline & $N$ & $M$ & Min & Max & \multicolumn{1}{c}{$S D$} \\
\hline Rejting & 26 & 1884,77 & 1591 & 2288 & 168,04 \\
KP postotak optimalne riješenosti & 26 & 12,50 & 0 & 50 & 14,60 \\
KP vrijeme odluke & 26 & 42,60 & 6,01 & 185,04 & 35,50 \\
KP procjena sigurnosti & 26 & 91,25 & 45 & 100 & 12,97 \\
KP proporcija broja fiksacija & 24 & 0,13 & 0 & 0,58 & 0,12 \\
KP proporcija vremena fiksacija & 24 & 0,12 & 0 & 0,62 & 0,13 \\
OP postotak optimalne riješenosti & 26 & 10,60 & 0 & 50 & 14,40 \\
OP vrijeme odluke & 26 & 40,52 & 6,05 & 96,14 & 21,99 \\
OP postotak sigurnosti & 26 & 93,08 & 60 & 100 & 11,75 \\
OP proporcija broja fiksacije & 24 & 0,10 & 0 & 0,26 & 0,07 \\
OP proporcija vremena fiksacija & 24 & 0,10 & 0 & 0,30 & 0,08 \\
\hline
\end{tabular}


očnih fiksacija na Einstellung poljima u odnosu na ukupno vrijeme i ukupan broj fiksacija na svim poljima.

Sve distribucije korištenih varijabli značajno ne odstupaju od normalne, osim razine sigurnosti, kako je utvrđeno Kolmogorov-Smirnovljevim testom. Kako bi se odgovorilo na postavljene ciljeve ispitivanja utjecaja perspektive i redoslijeda na svim zavisnim varijablama, korištena je analiza kovarijance s rejtingom kao kovarijatom. Rezultati tih analiza prikazani su u tablicama 2 i 3.

Tablica 2. Prikaz analize kovarijance na različitim zavisnim varijablama s obzirom na perspektivu (konvencionalna i obrnuta) uz kovarijatu rejtinga

\begin{tabular}{lccc}
\hline & $F$ & $P$ & $\eta_{\mathrm{p}}{ }^{2}$ \\
\hline Vrijeme odlučivanja & 1,02 & 0,32 & 0,04 \\
Postotak optimalne riješenosti & 1,09 & 0,31 & 0,04 \\
Proporcija vremena fiksacija na E-poljima & 0,38 & 0,54 & 0,02 \\
Proporcija broja fiksacija na E-poljima & 0,33 & 0,57 & 0,01 \\
Razina sigurnosti & 0,34 & 0,57 & 0,01 \\
\hline
\end{tabular}

$\eta_{\mathrm{p}}^{2}-$ veličina efekta - parcijalna kvadrirana eta

Tablica 3. Prikaz analize kovarijance na različitim zavisnim varijablama s obzirom na redoslijed (konvencionalna-obrnuta i obrnuto-konvencionalna) uz kovarijatu rejtinga

\begin{tabular}{lccc}
\hline & $F$ & $p$ & $\eta_{\mathrm{p}}{ }^{2}$ \\
\hline Vrijeme odlučivanja & 9,85 & 0,01 & 0,30 \\
Postotak optimalne riješenosti & 0,29 & 0,60 & 0,01 \\
Proporcija vremena fiksacija na E-poljima & 0,05 & 0,83 & 0 \\
Proporcija broja fiksacija na E-poljima & 1,23 & 0,28 & 0,06 \\
Razina sigurnosti & 2,10 & 0,16 & 0,08 \\
\hline
\end{tabular}

$\eta_{p}{ }^{2}-$ veličina efekta - parcijalna kvadrirana eta

Testiranjem utjecaja perspektive pokazalo se da nema značajnog efekta ni na jednoj zavisnoj varijabli (Tablica 2). Nadalje, testiranjem efekta redoslijeda pokazalo se da postoji značajan efekt na vremenu odlučivanja (Tablica 3). Grupa šahista koja je rješavala probleme redoslijedom s konvencionalnom pa obrnutom perspektivom imala je duže vrijeme rješavanja. Efekti u drugim zavisnim varijablama nisu se pokazali značajnima.

Efekt perspektive na vrijeme i broj fiksacija na poljima za optimalno i E-rješenje testiran je analizom varijance. Testiranjem su utvrđene razlike u proporciji vremena 


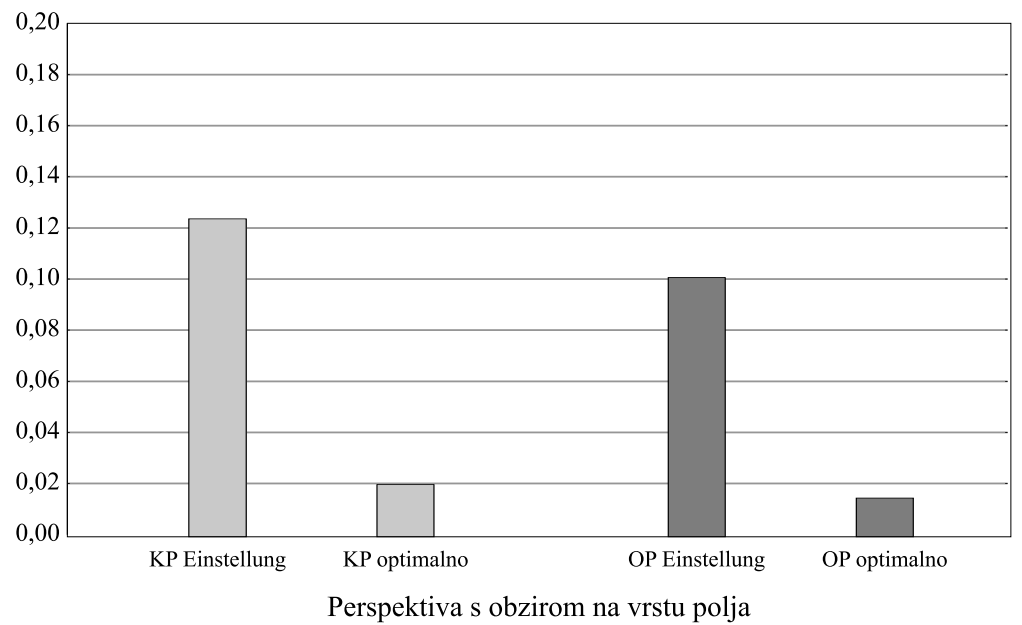

Slika 2. Prikaz razlike proporcija vremena fiksacije konvencionalne (KP) i obrnute (OP) perspektive kod optimalnih i Einstellung polja.

fiksacija kod obje perspektive s obzirom na vrstu polja $\left(F=10,7, p<0,01, \eta_{\mathrm{p}}{ }^{2}=\right.$ 0,33). Ispitanici su u obje perspektive, u podjednakoj mjeri, duže pogledavali polja relevantna za E-rješenje nego za optimalno rješenje (Slika 2). Isti efekt na proporciju broja očnih fiksacija nije značajan.

Radi testiranja efekta šahovskog rejtinga igrači su podijeljeni prema medijanu $(C=1865)$ u skupinu višeg i nižeg rejtinga $\left(N_{1}=13, N_{2}=13\right)$. Dakle, kategorije se sastoje od igrača jačine prve i druge kategorije, i kategorije majstorskih kandidata. Prosječna vrijednost rejtinga prve kategorije iznosi 2020, s rasponom od 1880 do 2288, a druge kategorije 1750, s rasponom od 1591 do 1850 . T-testom za nezavisne uzorke testiran je efekt rejtinga na svim zavisnim varijablama. Dva ispitanika iz grupe višeg rejtinga nisu se pridržavali upute pri bilježenju pokreta očiju te su njihovi rezultati za vrijeme i broj očnih fiksacija izuzeti iz analize.

Tablica 4. Prikaz t-testova na različitim zavisnim varijablama s obzirom na višu ili nižu razinu rejtinga $\left(\mathrm{N}_{1}=13, \mathrm{~N}_{2}=13\right)$

\begin{tabular}{lcccccc}
\hline & $\begin{array}{c}\text { Igrači više } \\
\text { razine }\left(M_{V}\right)\end{array}$ & $\begin{array}{c}\text { Igrači niže } \\
\text { razine }\left(M_{N}\right)\end{array}$ & t-vrijednost & $d f$ & $p$ & $d$ \\
\hline Vrijeme donošenja odluka & 74,6 & 91,7 & 0,92 & 24 & 0,37 & 0,36 \\
Postotak optimalne riješenosti & 32,7 & 13,50 & $-2,14$ & 24 & 0,04 & 0,84 \\
Proporcija vremena fiksacija & 0,19 & 0,26 & 1,39 & 22 & 0,18 & 0,58 \\
Proporcija broja fiksacija & 0,19 & 0,25 & 1,08 & 22 & 0,29 & 0,50 \\
\hline
\end{tabular}

$d$ - jačina efekta - Cohenov $d$ 
Utvrđena je značajna razlika u postotku optimalne riješenosti između šahista višeg i nižeg rejtinga (Tablica 4). Igrači višeg rejtinga imali su veći postotak optimalne riješenosti nego igrači nižeg rejtinga. Također je Mann-Whitney testom utvrđena značajna razlika $\left(C_{1}=100, C_{2}=92,5 U=38, p<0,05\right)$ u razini sigurnosti u vlastiti odgovor (u daljnjem tekstu - razina sigurnosti). Šahisti višeg rejtinga imali su veću razinu sigurnosti u svoja rješenja nego igrači nižeg rejtinga. Na to upućuje i Spearmanov koeficijent korelacije između rejtinga i razine sigurnosti u odgovor $(\rho=0,56$; $p<0,05)$. Šahisti koji postižu viši rejting imaju i višu razinu sigurnosti u vlastito rješenje. Ovaj nalaz upućuje na to kako iskusniji igrači, u Einstellung problemima, imaju veću razinu sigurnosti prilikom odigravanja poteza. Na ostalim varijablama vremena i broja fiksacija, te ukupnog vremena odlučivanja nije utvrđena značajna povezanost.

\section{RASPRAVA}

Ciljevi istraživanja bili su ispitati utjecaj perspektive i razine šahovskog rejtinga na E-efekt u šahovskim problemima. Pretpostavilo se da će obrnuta perspektiva utjecati na veću uspješnost u pronalasku optimalnih rješenja, duže vrijeme odlučivanja, manji broj fiksacija i manje vremena gledanju polja za E-rješenje te nižu razinu sigurnosti. Nije utvrđen efekt perspektive na učestalost optimalnog rješavanja. Nepostojanje razlike upućuje na to kako je E-efekt bio podjednako zastupljen u obje eksperimentalne situacije. Iz Tablice 1 se može uočiti da se kod obje grupe javio E-efekt jer su bile podjednako neuspješne u učestalosti pronalaska optimalnog rješenja (svega oko 10\%). Objašnjenje ovakvog nalaza implicira nepostojanje efekta obrnute perspektive na povećanje efikasnosti u rješavanju Einstellung šahovskih problema.

Istraživanja upućuju da u slučaju prisutnosti poznatog (E-rješenje) i optimalnog rješenja ispitanici imaju kraće vrijeme prilikom donošenja odluka za razliku od ispitanika kojima poznato rješenje nije prezentirano (Bilalić i sur., 2008b). Vješti igrači imaju brzo dozivanje poznate odgovarajuće pozicijske teme i pronalazak sukladnog rješenja (Gobet i Simon, 1996), no nemogućnost pronalaska optimalnog rješenja vodi nižem kriteriju prihvaćanja odluke za potez i veće sigurnosti (Bilalić i sur., 2010), osobito u situacijama niskog uloga (low-stakes) kao što je ova. Drugim riječima, unutar poznatog konteksta igrač se lakše odlučuje za poznati potez ako ne pronađe drugačiji (optimalan), što je slučaj u E-pozicijama. S druge strane obrnuta perspektiva mogla bi onemogućiti prepoznavanja chunka i time produžiti vrijeme pretrage i sniziti sigurnost zbog neuobičajenog uvjeta. Rezultati ovog rada pokazuju kako ne postoji razlika u vremenu odlučivanja ni u razini sigurnosti s obzirom na perspektivu (Tablica 2).

Redoslijed situacija je prvenstveno manipuliran radi kontrole u eksperimentu. Utvrđen je značajan efekt redoslijeda eksperimentalnih situacija na vrijeme odlu- 
čivanja, ali ne i na druge zavisne varijable. Šahisti su imali kraće vrijeme u slučaju kada su rješavali probleme redoslijedom obrnuto-konvencionalno (redoslijed 2), samo u slučaju obrnute perspektive, što se odrazilo i na generalnu razinu. Dva su moguća objašnjenje ovog rezultata. Prvo, perspektive možda djeluju kao priming efekt jedna na drugu tako da prvo izlaganje obrnutoj perspektivi skraćuje rješavanje u sljedećem izlaganju u konvencionalnoj perspektivi i obrnuto. Drugo, moguće da je efekt slučajan te bi ga trebalo testirati na novom i većem uzorku.

Bilalić i suradnici (2008b) su bilježenjem očnih pokreta utvrdili da šahisti, u prisutnosti poznatog i optimalnog rješenja, provode više vremena gledajući polja relevantna za poznato rješenje. Iz navedenog autori zaključuju da šahisti, u prisutnosti poznatog rješenja, nisu uspijevali pronaći optimalno rješenje, bez obzira što su u manjoj mjeri pogledavali polja za optimalno rješenje. U prilog istraživanjima (Bilalić i sur., 2008b; Ellis i Reingold, 2014) idu rezultati ovog istraživanja (Slika 2), jer prikazuju da ispitanici u obje perspektive imaju viši udio vremena fiksacije na poljima relevantnim za poznato rješenje nego na poljima za optimalno rješenje, dok nije utvrđena značajna razlika u broju fiksacija. Iz ovog nalaza proizlazi da su šahisti jednakom čestinom pogledavali polja za oba rješenja, no da su duže zadržavali pogled na poljima relevantnim za E-rješenje. Ovakav nalaz implicira da su se ispitanici u obje perspektive kratko zadržavali na poljima za optimalno rješenje i time nisu mogli značajno uvidjeti važnost tih polja, što također navode u svom radu Bilalić i suradnici (2008b). Šahisti nisu mogli ubaciti nove elemente u poznatu predodžbu za uspješno rješavanje problema kako objašnjavaju Ellis i Reingold (2014).

Očekivalo se da će šahisti imati manji udio vremena i broja fiksacija u obrnutoj perspektivi na poljima za E-rješenje nego u konvencionalnoj perspektivi. Utvrđivanje utjecaja obrnute perspektive na smanjenje udjela vremena i broja fiksacija na poljima za E-rješenje nije rezultiralo značajnim efektom (Tablica 2), kao što nije ni očitovan efekt redoslijeda zadavanja problema na promjenu udjela (Tablica 3). Dakle, obrnuta perspektiva nije uspjela sniziti utjecaj parametara E-efekta. Ovakvi rezultati sugeriraju da je postojanje poznatog rješenja održalo E-efekt jakim u obje perspektive. Treba napomenuti i da su u eksperimentu sudjelovali vješti šahisti, što je možda utjecalo da prilikom mjerenja nisu obuhvaćena sva polja uključena u konstrukciju konfiguracije poteza (chunka) zbog korištenja perifernih procesa (Charness i sur., 2001). Isti autori prikazuju da vješti šahisti imaju fiksacije uzduž ruba polja, stoga je moguće da je došlo do nesustavne pogreške mjerenja, jer je sustav praćenja pokreta očiju, zbog nepreciznosti, mogao zahvatiti polja koja nisu uključena u mjerenje.

S obzirom na drugi cilj istraživanja, na temelju prethodne evidencije, očekivalo se da će se neovisno o rejtingu u rasponu umjereno jakih šahista pojaviti podjednak utjecaj E-efekta, dok bi vrlo jaki šahisti trebali imati višu razinu sigurnosti i kraće vrijeme rješavanja. U nekoliko radova (Bilalić i sur., 2008a; Anderson i Lebiere, 1998; Logan, 1988) navode kako su samo najjači šahisti (velemajstori) otporni na Eefekt, dok će se kod ostalih jakih igrača (ostale niže kategorije) podjednako pojav- 
ljivati efekt. U ovom istraživanju, suprotno očekivanju, utvrđeno je da jaki šahisti ipak imaju veću vjerojatnost uspješnog pronalaska optimalnog rješenja (Tablica 4), kao i veću razinu sigurnosti od nešto slabijih igrača. S druge strane, obje skupine su imale podjednako vrijeme odlučivanja i pogledavanja polja relevantna za E-efekt. Sheridan i Reingold (2013) ističu kako trend da eksperti, u odnosu na neiskusne šahiste (početnike), imaju niže vrijeme fiksacija i veći broj fiksacija na poljima relevantnim za E-rješenje. Ipak u ovom istraživanju ispitanici nisu bili toliko ekstremno polarizirani pa je moguće da su se te razlike u vremenu i broju fiksacija izjednačile. Također, iako su obje grupe bile relativno zahvaćene E-efektom, jači igrači su pokazali bolju izvedbu upravo zbog tog što imaju bolju sposobnost pronalaska jakih poteza kao što su i pokazali Chase i Simon (1973).

Konačno, treba uzeti u obzir da je jedno od mogućih ograničenja ovog istraživanja relativno mali uzorak (zbog svoje specifične prirode), što umanjuje statističku snagu pri analizama kao i mogućnost generaliziranja podataka. Nadalje, preciznost sustava za praćenje očiju nije vrhunska, iako je dovoljna za bilježenje očnih fiksacija i njihovih trajanja. Nadalje, dodatna primjedba odnosi se na to da obrtanje 2D perspektive nije isto što i obrtanje 3D perspektive, što otvara mogućnost da se slično istraživanje provede pri korištenju realnije situacije na pravim šahovskim tablama.

\section{ZAKLJUČCI}

1. Nije utvrđen efekt obrnute perspektive na smanjenje Einstellung efekta $u$ šahovskim problemskim zadacima.

2. Trajanje očnih fiksacija na poljima koja su u osnovi za Einstellung rješenje je duže od fiksacija na poljima za optimalno rješenje.

3. Šahisti u kategoriji višeg šahovskog rejtinga imali su veći postotak optimalne riješenosti kao i veću procjenu sigurnosti od onih u kategoriji nižeg rejtinga.

\section{LITERATURA}

Amabile, T. M. (1989). Growing up creative: Nurturing a lifetime of creativity. New York, NY: Crown Publishers.

Anderson, J. R., i Lebiere, C. (1998). The atomic components of thought. Hillsdale, NJ: Lawrence Erlbaum Associates.

Bilalić, M., McLeod, P., i Gobet, F. (2008a). Inflexibility of experts - Reality or myth? Quantifying the Einstellung effect in chess masters. Cognitive Psychology, 56, 73-102. https://doi.org/10.1016/j.cogpsych.2007.02.001

Bilalić, M., McLeod, P., i Gobet, F. (2008b). Why good thoughts block better ones: The mechanism of the pernicious Einstellung (set) effect. Cognition, 108(3), 652-661. https://doi.org/10.1016/j.cognition.2008.05.005 
Bilalić, M., McLeod, P., i Gobet, F. (2010). The mechanism of the Einstellung (set) effect. Current Directions in Psychological Science, 19(2), 111-115. https://doi. org/10.1177/0963721410363571

Burns, B. D. (2004). The effects of speed on skilled chess performance. Psychological Science, 15(7), 442-447. https://doi.org/10.1111/j.0956-7976.2004.00699.x

Ellis, J., i Reingold, E. (2014). The Einstellung effect in anagram problem solving: Evidence from eye movements. Frontiers in Psychology, 5. https://doi.org/10.3389/ fpsyg.2014.00679

Chase, W. G., i Simon, H. A. (1973). Perception in chess. Cognitive Psychology, 4, 55-81. https://doi.org/10.1016/0010-0285(73)90004-2

Charness, N., Reingold, E., Pomplun, M., i Stampe, D. (2001). The perceptual aspect of skilled performance in chess: Evidence from eye movements. Memory \& Cognition, 29(8), 1146-1152. https://doi.org/10.3758/BF03206384

de Groot, A. D., i Gobet, F. (1996). Perception and memory in chess: Heuristic of the professional eye. Assen: Van Gorcum.

Ferrari, V., Didierjean, A., i Marmèche, E. (2006). Dynamic perception in chess. Quarterly Journal of Experimental Psychology, 59(2), 397-410. http://dx.doi. org/10.1080/17470210500151428

Frey, P., i Adesman, P. (1976). Recall memory for visually presented chess positions. Memory \& Cognition, 4(5), 541-547. http://dx.doi.org/10.3758/BF03213216

Gobet, F., i Simon, H. A. (1996). Templates in chess memory: A mechanism for recalling several boards. Cognitive Psychology, 31, 1-40. http://dx.doi.org/10.1006/cogp.1996.0011

Gobet, F., i Simon, H. A. (1998). Expert chess memory: Revisiting the chunking hypothesis. Memory, 6(3), 225-255. https://doi.org/10.1080/741942359

Gobet, F., i Simon, H. A. (2000). Five seconds or sixty? Presentation time in expert memory. Cognitive Science, 24, 651-682. https://doi.org/10.1207/s15516709cog2404_4

Gong, Y., Ericsson, K., i Moxley, J. (2015). Recall of briefly presented chess positions and its relation to chess skill. PLOS ONE. 10(3): e0118756. https://doi.org/ 10.1371/journal. pone. 0118756

Logan, G. D. (1988). Toward an instance theory of automatization. Psychological Review, 95, 492-527. http://dx.doi.org/10.1037/0033-295X.95.4.492

Luchins, A. S. (1942). Mechanization in problem solving: The effect of Einstellung. Psychological Monographs, 54(6), i-95. http://dx.doi.org/10.1037/h0093502

Miller, G. A. (1956). The magical number seven, plus or minus two: Some limits on our capacity for processing information. Psychological Review. 63 (2), 81-97. https://dx.doi. org/10.1037/h0043158

Reingold, E., Charness, N., Schultetus, R., i Stampe, D. (2001). Perceptual automaticity in expert chess players: Parallel encoding of chess relations. Psychonomic Bulletin \& Review. 8(3), 504-510. http://dx.doi.org/BFO3196185

Saariluoma, P. (1990). Apperception and restructuring in chess players' problem solving. In K. J. Gilhooly, M. T. Keane, R. H. Logie, \& G. Erdos (Eds.). Lines of Thinking: Reflections on the Psychology of Thought (Vol. 2, 41-57). Oxford, England: John Wiley \& Sons. 
Sheridan, H., i Reingold, E. (2013). The mechanisms and boundary conditions of the einstellung effect in chess: evidence from eye movements. PLOS ONE. 8(10): e75796. https://doi.org/ 10.1371/journal.pone.0075796

Simon, H. A., i Gilmartin, K. (1973). A simulation of memory for chess positions. Cognitive Psychology, 5(1), 29-46. http://dx.doi.org/10.1016/0010-0285(73)90024-8

\title{
THE EFFECT OF REVERSE PERSPECTIVE AND PLAYER'S RATING ON FLEXIBLE THINKING IN CHESS
}

\begin{abstract}
The Einstellung effect (E-effect) is described in the psychology of chess as a mental set that makes chess players inflexible to optimize chess tactics when a familiar solution is present. The perception of experienced chess players allows quick pattern recognition among chess figures by grouping them into configurations with the quick finding of a familiar solution as a result. The so-called fast mechanism has a main role in this process, such as recognition, while finding the optimal solution in the same situation requires a more prominent slower mechanism, such as field search. The reverse perspective (RP) of chess position might be the technique that could affect this slower mechanism activation. In a situation where the fast mechanism is ineffective, a perceptively vague position, caused by RP, may activate a different approach in establishing relationships among figures. The aim of this study was to examine the effect of the $\mathrm{RP}$ on the reduction of E-effect, and to determine the rating influence on the E-effect. Experiment subjects were chess club players $(\mathrm{N}=26)$ with a national chess rating who were to solve a set of chess problems with a manipulated perspective. The perspective and rating effect were investigated regarding the frequency of optimal solution, decision time, time and number of fixation on the fields relevant for the Einstellung solution and the confidence level. The results indicate that the reverse perspective did not have any effect on a series of dependent variables, while the sequence of presented problems showed impact on decision time. It was also found that more experienced chess players resolve an optimal solution more often and had a higher level of confidence. The player's rating shows the strongest effect on flexible thinking in chess.
\end{abstract}

Key words: chess, reverse perspective, player's rating, Einstellung effect, flexible thinking

Primljeno: 08. 06. 2019. 
